\title{
ŠEIMOS GYDYTOJO PACIENTŲ, VARTOJANČIU BENZODIAZEPINUS, PRIKLAUSOMYBĖS IŠSIVYSTYMO TENDENCIJOS
}

\author{
Ramūnas Aranauskas ${ }^{1}$, Laura Vaičiulienė ${ }^{2}$ \\ ${ }^{1}$ Vilniaus universiteto Medicinos fakulteto Psichiatrijos klinika, \\ ${ }^{2}$ Vilniaus universiteto Medicinos fakulteto Šeimos medicinos centras
}

Raktažodžiai: benzodiazepinai, priklausomybè, vartojimas, priklausomybės diagnostiniai kriterijai.

\section{Santrauka}

Benzodiazepinai (BZD) yra viena iš daugiausiai skiriamų vaistų grupių tiek psichiatrineje, tiek bendrojoje praktikoje. Nors rekomenduojama juos vartoti ne ilgiau kaip 4 savaites, dauguma pacientu juos vartoja žymiai ilgiau, kas padidina nepageidaujamu poveikių bei priklausomybès nuo BZD vystymosi riziką. Šio darbo tikslas: nustatyti priklausomybès nuo BZD išsivystymo tendencijas tarp juos vartojančių šeimos gydytojo pacientų. Šiam tyrimui specialiai paruošta anoniminè anketa. Siekiant nustatyti galimą priklausomybę nuo BZD, buvo pateikti 7 klausimai, sudaryti remiantis DSM-IV priklausomybės diagnostiniais kriterijais. Priklausomybę galima ịtarti, jei ị tris ir daugiau klausimų atsakoma teigiamai. Atlikta šeimos gydytojo pacientų, 18 m. ir vyresnių, vartojančių benzodiazepinų klasės preparatus, apklausa. Duomenų analizei naudotas SPSS 17.0 programinis paketas. Iš viso išdalinta 119 anketų, duomenų analizei naudota 101. Leidimas atlikti apklausą gautas. Rezultatai: tarp tiriamujų vyravo moteriškos lyties, vyresnio amžiaus, vieniši (nesusituokę/išsiskyrę/našliai), gaunantys mažas pajamas, žemesnio išsilavinimo asmenys. Dažniausiai nurodyta vartojimo priežastis nemiga, vidutinè vartojimo trukmè - 86 mènesiai, beveik pusė apklaustujų nurodė geriantys vaistus kasdien. Nustatytas tikètinos priklausomybès nuo BZD dažnis tiriamuju populiacijoje - 37,6\%. Statistiškai patikimai dažniau tendencija vystytis priklausomybei nustatyta asmenims, vartojantiems vaistus kasdien $(p<0,001)$, mažesnes pajamas gaunantiems ( $p=$
$0,013)$, žemesnio išsilavinimo $(p=0,023)$, kaip vartojimo priežastị nurodžiusiems nerimą $(\mathrm{p}=0,021)$, kuriems diagnozuota psichinė liga $(\mathrm{p}=0.027)$, sulaukusiems pensinio amžiaus ( $\mathrm{p}=0,003)$, bei kuriuos dèl ligos vargina nuolatinis skausmas $(\mathrm{p}=0,005)$. Tuo tarpu vedybine padètis, žalingi ịpročiai, gydytojo, išrašančio receptus, specializacija, vartojamo BZD grupés preparato pasirinkimas statistiškai reikšmingo ryšio priklausomybès vystymuisi neturejo.

\section{Ivadas}

Šeimos gydytojai paprastai pirmieji susiduria su pacientais, besiskundžiančiais nemigos, depresijos ar nerimo simptomais. Kanados mokslininkų atliktas tyrimas parodé, kad išsivysčiusiose šalyse apie $80 \%$ populiacijos per metus bent kartą kreipiasi ị šeimos gydytoją, iš jų nuo 20\% iki 40\% kaip pagrindinę ar vieną iš priežasčių nurodo psichologines problemas ar psichikos sutrikimus, tarp kurių dažniausiai pasitaiko depresija, nerimo sutrikimai - antroje vietoje [1]. Be to, labai dažnai šie sutrikimai pasireiškia kartu.

Benzodiazepinai dažniausiai skiriami nemigai bei nerimui gydyti. Nors mokslinių tyrimų duomenimis, kasdien vartojant juos ilgiau nei ménesi, jų poveikis sumažeja, atsiranda tolerancija, dauguma pacientų juos vartoja žymiai ilgiau, nepaisydami pašalinių šių vaistų poveikių, tokių kaip galvos svaigimas, atminties susilpnèjimas, sumažejusi psichomotorinè koordinacija, priklausomybè, kas padidina nelaimingų atsitikimų, traumų, perdozavimo, agresyvaus elgesio, fizinio smurto, darbo praradimo riziką, ir nors sunku tiksliai ịvertinti, dèl to labai išauga socioekonominiai kaštai [2]. Šie padariniai galètų būti minimalūs, jei vaistai būtų skiriami ir vartojami racionaliai, ypač vyresnio amžiaus žmonèms.

Pastaraisiais metais Lietuvoje BZD ir kitų priklausomybę sukeliančių vaistų išrašymo tvarka buvo sugriežtinta - BZD 
ịtraukti į psichotropinių vaistų sąrašą, reglamentuotos jų išrašymo taisyklès [3]. Tačiau iki šiol duomenų apie realią BZD vartojimo situaciją Lietuvoje yra nepakankamai.

Darbo tikslas: nustatyti priklausomybès nuo BZD išsivystymo tendencijas tarp juos vartojančių šeimos gydytojo pacientu.

\section{Tyrimo objektas ir metodika}

Tiriant taip pat siekta išsiaiškinti bendrus sociodemografinius bruožus, BZD vartojančių populiacijoje, vaistų vartojimo priežastis, trukmę, dažnį; nustatyti tikètinos priklausomybès nuo BZD dažnị tarp vartojančiųjų; išsiaiškinti ryšius tarp biosociodemografinių faktorių bei priklausomybès nuo BZD vystymosi.

1 lentelė. Pasiskirstymas pagal požymius

\begin{tabular}{|c|c|c|c|}
\hline $\begin{array}{l}\text { Biologiniai, demografiniai } \\
\text { ir socialiniai veiksniai }\end{array}$ & & $\mathbf{N}$ & $\%$ \\
\hline \multirow[t]{2}{*}{ Lytis } & moterys & 74 & 73,3 \\
\hline & vyrai & 27 & 26,7 \\
\hline \multirow[t]{4}{*}{ Amžiaus grupė } & $18-30 \mathrm{~m}$. & 2 & 2,0 \\
\hline & $31-50 \mathrm{~m}$. & 8 & 7,9 \\
\hline & $51-65 \mathrm{~m}$. & 39 & 38,6 \\
\hline & $66-99 \mathrm{~m}$. & 52 & 51,5 \\
\hline Gyvenamoji vieta & miestas & 101 & 100 \\
\hline \multirow[t]{2}{*}{ Vedybinis statusas } & $\begin{array}{l}\text { Vieniši/nesituokę/išsi- } \\
\text { skyrę/našliai }\end{array}$ & 55 & 54,5 \\
\hline & $\begin{array}{l}\text { Vedęs/ištekèjusi/turi } \\
\text { draugą/-ę }\end{array}$ & 46 & 45,5 \\
\hline \multirow[t]{3}{*}{ Išsilavinimas } & Pradinis/pagrindinis & 8 & 7,9 \\
\hline & \begin{tabular}{|l|} 
Vidurinis/aukštesnysis \\
\end{tabular} & 70 & 69,3 \\
\hline & Aukštasis & 23 & 22,8 \\
\hline \multirow[t]{4}{*}{ Užimtumas } & Protinis darbas & 12 & 11,9 \\
\hline & Fizinis darbas & 8 & 7,9 \\
\hline & Senatvès pensija & 69 & 68,3 \\
\hline & Bedarbis & 12 & 11,9 \\
\hline \multirow{3}{*}{$\begin{array}{l}\text { Vidutinès mėnesio paja- } \\
\text { mos }\end{array}$} & $<400 €$ & 79 & 78,2 \\
\hline & $400-800 €$ & 20 & 19,8 \\
\hline & $>800 €$ & 2 & 2,0 \\
\hline Gyvena vienas/-a & Taip & 27 & 26,7 \\
\hline \multirow[t]{5}{*}{ Alkoholio vartojimas } & Visai nevartoja & 48 & 47,5 \\
\hline & Tik per šventes & 49 & 48,5 \\
\hline & 1-2 kartus per savaitę & 4 & 4,0 \\
\hline & 3-5 kartus per saveitę & 0 & 0 \\
\hline & kasdien & 0 & 0 \\
\hline Rūkantys & & 17 & 16,8 \\
\hline Diagnozuota psichinė liga & & 12 & 11,9 \\
\hline Jaučia nuolatinị skausmą & & 65 & 64.4 \\
\hline Iš viso & & 101 & 100 \\
\hline
\end{tabular}

Tyrimui sudaryta speciali struktūrizuota anoniminè anketa bei atlikta šeimos gydytojo pacientu, $18 \mathrm{~m}$. ir vyresnių, vartojančių benzodiazepinų klasės preparatus, apklausa. Apklausa vykdyta Šeškinès poliklinikoje 2012 m. Anketa pateikta lietuvių ir rusų kalbomis. Dalyvių prašyta nurodyti biosocialinius ir demografinius duomenis, pažymèti vartojamus BZD grupès preparatus, jų vartojimo dažnị ir trukmę, nurodyti, iš kur gauna receptus vaistams, ar yra diagnozuota psichinè liga, ar lanko psichoterapiją, ar dèl kokios nors ligos jaučia nuolatinị skausmą. Siekiant ịvertinti galimą priklausomybę nuo benzodiazepinų, buvo pateikti septyni klausimai, sudaryti remiantis Amerikos psichiatrijos asociacijos diagnostikos ir statistikos vadovo ketvirtos redakcijos (angl. Diagnostical and Statistical Manual, 4th revision, toliau DSM-IV) priklausomybės diagnostiniais kriterijais. Klausimyno skalès balų skaičius - nuo 0 iki 7. Priklausomybe ịtariama, surinkus tris ir daugiau balų skaičių. Klausimyno vidiniam nuoseklumui (angl. scale internal consistency) ivertinti naudotas Kronbacho alfa (Cronbach's alpha) koeficientas (0.714). Duomenų analizė atlikta naudojant SPSS 17.0 programini paketą (Statistical Package for Social Science). Dviejų aritmetinių vidurkių skirtumo patikimumas tikrintas taikant Stjudento (t) (Student) kriterijų. Nominalinių rodiklių
2 lentelè

\begin{tabular}{|l|c|}
\hline $\begin{array}{l}\text { Preparato pavadi- } \\
\text { nimas }\end{array}$ & N(\%) \\
\hline Lorazepamas & $43(42,6)$ \\
\hline Diazepamas & $16(15,8)$ \\
\hline Bromazepamas & $17(16,8)$ \\
\hline Alprazolamas & $8(7,9)$ \\
\hline Dikalio klorazepatas & $5(5,0)$ \\
\hline Oksazepamas & $2(2,0)$ \\
\hline Nitrazepamas & $4(4,0)$ \\
\hline Klonazepamas & $14(13,9)$ \\
\hline Chlordiazepoksidas & $6(5,9)$ \\
\hline Triazolamas & $2(2,0)$ \\
\hline
\end{tabular}

4 lentelè

\begin{tabular}{|l|c|}
\hline $\begin{array}{l}\text { K I a u - } \\
\text { si m y n o } \\
\text { ivertis }\end{array}$ & N (\%) \\
\hline 0 & $19(18,8)$ \\
1 & $30(29,7)$ \\
2 & $14(13,9)$ \\
3 & $10(9,9)$ \\
4 & $19(18,8)$ \\
5 & $2(2,0)$ \\
6 & $7(6,9)$ \\
Iš viso & $101(100)$ \\
\hline
\end{tabular}

3 lentelè

\begin{tabular}{|l|c|c|}
\hline $\begin{array}{l}\text { Vartoji mo } \\
\text { t r u k m e e } \\
\text { (mėn.) }\end{array}$ & (N) & $(\mathbf{\%})$ \\
\hline 2,00 & & \\
6,00 & 2 & 2,0 \\
12,00 & 2 & 2,0 \\
24,00 & 8 & 7,9 \\
36,00 & 22 & 21,8 \\
48,00 & 10 & 9,9 \\
60,00 & 2 & 2,0 \\
72,00 & 10 & 9,9 \\
84,00 & 2 & 2,0 \\
108,00 & 6 & 5,9 \\
120,00 & 2 & 2,0 \\
240,00 & 26 & 25,7 \\
360,00 & 2 & 2,0 \\
Iš viso & 7 & 6,9 \\
\end{tabular}

Pagal DSM-IV nustatyta tikètina priklausomybè nuo BZD

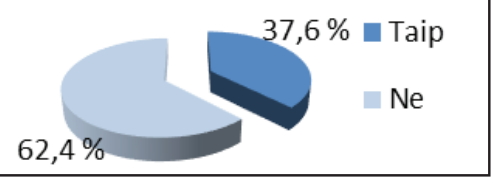

1 paveikslas 
priklausomumas tikrintas chi kvadrato $\left(\chi^{2}\right)$ testu. Duomenys laikyti statistiškai reikšmingi, kai p reikšmė $<0,05$.

\section{Rezultatai}

Bendra tiriamos populiacijos charakteristika. Iš viso išdalinta 119 anketų, dèl negrąžintų ar netinkamai užpildytų duomenų analizei naudota 101 anketa (atsako dažnis - 84,87 \%). Tarp tiriamujų vyravo moteriškos lyties, vieniši (nesusituokę/išsiskyrę/našliai), gaunantys mažas pajamas, žemesnio išsilavinimo asmenys. Dauguma nurode gyvenantys ne vieni. Daugiau kaip pusè apklaustujų buvo 66 metų amžiaus ir vyresni (1 lentelè). Nustatytas nedidelis alkoholio vartojimas: $96 \%$ nurodè nevartojantys arba vartojantys tik per šventes (kelis kartus per metus) bei rūkymo paplitimas (1 lentelè). Galbūt dèl to, kad tarp tiriamujų vyravo vyresnio amžiaus žmonès. 11,9 \% apklaustujų nurodè, kad jiems yra diagnozuota psichinè liga, tačiau nei vienas niekada nelankè psichoterapijos. Daugiau kaip pusè $(64,4 \%)$ pažymėjo jaučiantys nuolatinị skausmą dèl kokios nors ligos (1 lentelè).

Benzodiazepinu vartojimo tendencijos. Dauguma apklaustujų nurodé šiuo metu vartojantys vieną preparatą $86,7 \%(\mathrm{n}=87), 11,9 \%(\mathrm{n}=12)$ nurodè vartojantys $\mathrm{du}$, o $2,0 \%$ $(\mathrm{n}=2)$ pažymejjo, kad vartoja tris. Dažniausiai vartojami BZD grupès atstovai buvo: lorazepamas, bromazepamas, diazepamas, klonazepamas (2 lentelè).

Preparato vartojimo trukmè matuota mėnesiais. Vidutinè vartojimo trukmé - 86 mènesiai, t.y. daugiau kaip 7 metai $(85,94 \pm 89,12)$. Trumpiausias vartojimo periodas buvo 2 mèn., ilgiausias - 360 mèn. ( 3 lentelè).

Dažniausiai receptus vaistams išrašo šeimos gydytojas $(71,2 \%)$. Dažniausiai nurodyta vartojimo priežastis buvo nemiga (86,1\%). Beveik pusé, t.y. $49,5 \%$ vartojančiųų BZD nurodè geriantys juos kasdien, 23,8\% - 3-5 k./sav., 16,8 \% - 1-2 k./sav., 9,9\% - rečiau nei kartą per savaitę. Išanalizuotas klausimyno, naudoto priklausomybès nuo BZD tendencijoms nustatyti, ivertis bei tiriamujų pasiskirstymas pagal balų skaičiu (4 lentelè). Nustatytas tikètinos priklausomybès nuo BZD dažnis tiriamujų populiacijoje $-37,6 \%$ (1 paveikslas).

Analizuojant gautus duomenis, rasta, kad statistiškai patikimai dažniau tendencija vystytis priklausomybei nuo
BZD nustatyta asmenims, vartojantiems vaistus kasdien $(68,0 \%, p<0,001)$, mažesnes pajamas gaunantiems $(43,8 \%, p=0,013)$, žemesnio išsilavinimo $(75 \%, p=$ $0,023)$, kaip vartojimo priežastị nurodžiusiems - nerimą $(55,2 \%, \mathrm{p}=0,021)$, kuriems diagnozuota psichinè liga $(66,7 \%, p=0,027)$, išejusiems senatvès pensijos $(47,8 \%$, $\mathrm{p}=0,003)$, bei kuriuos dèl ligos vargina nuolatinis skausmas $(47,7 \%, \mathrm{p}=0,005)$. Tuo tarpu asmenims, kurie nurode vartojantys vaistus rečiau, t.y. $1-2 \mathrm{k} . / \mathrm{sav} .(11.8 \%, \mathrm{p}=0,016)$ ar rečiau nei $1 \mathrm{k} . / \mathrm{sav}$. $(\mathrm{p}=0,010)$, bei gaunantiems didesnes pajamas $(15,8 \%, p=0,029)$, statistiškai patikimai priklausomybès reiškinių nustatyta rečiau, o tarp dirbančiųjų tiek protini $(p=0,004)$, tiek fizini $(p=0,010)$ darbą nustatyta nebuvo (5 lentelè). Nestebètas statistiškai reikšmingas ryšys tarp priklausomybès išsivystymo bei tiriamųų vedybinès padèties, rūkymo bei alkoholio vartojimo, gydytojo išrašančio receptus, specializacijos, nuo to, kuris BZD grupès preparatas vartojamas, ir to, kad gyvena vienas ar ne vienas.

\section{Rezultatų aptarimas}

Analizuojant BZD vartotojų populiacijos socialines-demografines charakteristikas ir lyginant su studijų, atliktų kitose šalyse, duomenimis, išryškejja keli aiškūs bruožai tarp vartotojų dominuoja moterys, o vartojimo paplitimas dideja su amžiumi [4].

Atlikto tyrimo duomenimis, dažniausiai vaistų vartojimo priežastimi nurodyta nemiga - 86,1\%. LSMU 2016 m. atliktas tyrimas parodè, kad didžiajai daliai, t.y. $75,5 \%$ visų respondentų bent viena iš indikacijų buvo nemiga [5].

5 lentelė. Veiksniai, ịtakojantys didesnị priklausomybės nuo BZD dažnị

\begin{tabular}{|c|c|c|c|c|c|}
\hline \multirow{3}{*}{\multicolumn{2}{|c|}{ Veiksnys }} & \multicolumn{4}{|c|}{ BZD vartojantys $N=101$} \\
\hline & & \multicolumn{4}{|c|}{ Pg.DSM-IV tikètina priklausomybė nuo BZD } \\
\hline & & \multirow{2}{*}{$\begin{array}{c}\text { Taip } \\
\mathbf{N}=\mathbf{3 8}(\mathbf{3 7 , 6 \% )} \\
66,7 \%(8) \\
33,7 \%(30) \\
\end{array}$} & \multirow{2}{*}{$\begin{array}{c}\mathrm{Ne} \\
\mathbf{N}=\mathbf{6 3}(\mathbf{6 2}, \mathbf{4 \%} \%) \\
33,3 \%(4) \\
66,3 \%(59) \\
\end{array}$} & \multirow{2}{*}{$\begin{array}{c}\begin{array}{c}\text { Iš } \\
\text { viso }\end{array} \\
12 \\
89 \\
\end{array}$} & \multirow[b]{2}{*}{$\mathrm{p}=0,027$} \\
\hline Diagnozuota psichinè liga & \begin{tabular}{|l} 
Taip \\
$\mathrm{Ne}$ \\
\end{tabular} & & & & \\
\hline Nuolatinis skausmas & $\begin{array}{l}\text { Taip } \\
\mathrm{Ne}\end{array}$ & $\begin{array}{c}47,7 \%(31) \\
19,4 \%(7)\end{array}$ & $\begin{array}{l}52,3 \%(34) \\
80,6 \%(29)\end{array}$ & $\begin{array}{l}65 \\
36\end{array}$ & $\mathrm{p}=0,005$ \\
\hline Vartojimo priežastis - nerimas & $\begin{array}{l}\text { Taip } \\
\mathrm{Ne} \\
\end{array}$ & $\begin{array}{l}55,2 \%(16) \\
30,6 \%(22)\end{array}$ & $\begin{array}{l}44,8 \%(13) \\
69,4 \%(50)\end{array}$ & $\begin{array}{l}29 \\
72 \\
\end{array}$ & $\mathrm{p}=0,021$ \\
\hline Vartojimas - kasdien & \begin{tabular}{|l} 
Taip \\
$\mathrm{Ne}$ \\
\end{tabular} & $\begin{array}{c}68,0 \%(34) \\
7,8 \%(4)\end{array}$ & $\begin{array}{l}32,0 \%(16) \\
92,2 \%(47)\end{array}$ & $\begin{array}{l}50 \\
51\end{array}$ & $\mathrm{p}<0,001$ \\
\hline Užimtumas - senatvės pensija & $\begin{array}{l}\text { Taip } \\
\mathrm{Ne}\end{array}$ & $\begin{array}{c}47,8 \%(32) \\
17,6 \%(6)\end{array}$ & $\begin{array}{l}52,2 \%(35) \\
82,4 \%(28)\end{array}$ & $\begin{array}{l}67 \\
34\end{array}$ & $\mathrm{p}=0,003$ \\
\hline Pajamos $<400 € /$ mèn. & $\begin{array}{l}\text { Taip } \\
\mathrm{Ne}\end{array}$ & $\begin{array}{c}43,8 \%(35) \\
14,3 \%(3)\end{array}$ & $\begin{array}{l}56,3 \%(45) \\
85,7 \%(18)\end{array}$ & $\begin{array}{l}80 \\
21 \\
\end{array}$ & $\mathrm{p}=0,013$ \\
\hline $\begin{array}{l}\text { Pradinis/pagrindinis išsilavi- } \\
\text { nimas }\end{array}$ & $\begin{array}{l}\text { Taip } \\
\mathrm{Ne}\end{array}$ & $\begin{array}{c}75,0 \%(6) \\
34,4 \%(32)\end{array}$ & $\begin{array}{l}25,0 \%(2) \\
65,6 \%(61)\end{array}$ & $\begin{array}{c}8 \\
93\end{array}$ & $\mathrm{p}=0,023$ \\
\hline
\end{tabular}


Italijoje $68,2 \%$ pacientų vaistus vartojo nakčiai [6]. Austrijoje, kaip ir pas mus, daugiausia receptus išrašo šeimos gydytojai (atitinkamai 60\% ir 71,2\%)[7]. Panašus pirmojo paskyrusio benzodiazepinus gydytojų procentas LSMUL KK Šeimos medicinos klinikoje: šeimos gydytojas skyrè $65,31 \%$ atvejų, psichiatras $-24,49 \%$; bei Italijos tyrime: šeimos gydytojas - 70,0 \%, neurologas ar psichiatras $-9,7 \%$ [5]. Adomaitienès ir kt. tyrime tarp stacionare psichiatru konsultuotų pacientų 10,6\% atvejų pirmasis vaistus skyręs gydytojas buvo psichiatras ir daryta išvada, kad psichiatras konsultuoja per retai ir skiriamas gydymas - neadekvatus [8].

Mūsų atliktos studijos duomenimis, tikètinos priklausomybès nuo BZD dažnis 37,6 \%. Tai neabejotinai aukštas rodiklis. Panašus jis nustatytas ir Taivane $-36 \%$, tuo tarpu Kanadoje - 9,5\% [9-11]. 2011 m. VUL SK psichiatrijos skyriuje atlikto tyrimo metu BZD vartojimo dažnis tarp pacientu buvo $60 \%$, tuo tarpu priklausomybès nuo BZD reiškiniai nustatyti 44,4\% vartojusiujuc [12].

Vaistų vartojimo trukmè, kaip ir šioje (7,1 metai), taip ir kitų šalių studijose, varijuoja plačiose ribose, pvz., Austrijoje - 4,5 metų, Taivane 5,4 metai [9]. Nors rekomenduojama BZD vartoti tik trumpalaikiam gydymui, vis deltto nemaža dalis toliau reguliariai ir ilgai tęsia jų vartojimą. İvairios studijos parodè, kad dauguma vartoja vaistus ilgiau nei vienerius metus: LSMU atlikto tyrimo duomenimis, net $70 \%$ pacientu, Italijoje - 89,2 \%, Pakistane 42,4\%, Austrijoje $85 \%$ apklaustujų $[6,7,13]$. Kadangi vartojimo paplitimas didejja su amžiumi, neabejotinai aktuali problema tampa platus jų vartojimas vyresnio amžiaus žmonių populiacijoje. Mūsų tyrime daugiau nei pusė $(51,5 \%)$ buvo vyresni nei $65 \mathrm{~m}$., Italijoje atliktos studijos duomenimis, vyresnių nei $65 \mathrm{~m}$. amžiaus grupejje bendrojoje populiacijoje vartojimo paplitimas buvo $18,8 \%$; iš visų vartojančiǔjų BZD 56\% juos vartojo kasdien bei ilgiau nei 6 mèn., iš jų 70,1\% buvo $65 \mathrm{~m}$. ir vyresni [6].

Reguliarus ir ilgalaikis BZD vartojimas susijęs su daugybe neigiamų sveikatai pasekmių, išaugusių medicininių išlaidų ir socialine žala. Naujojo Pietų Velso (Australija) sveikatos departamento išleistose gairèse teigiama, kad priklausomybė nuo BZD, vartojant juos trumpiau kaip 3 mèn., išsivysto nedidelei daliai vartojančių, vartojant nuo 3 iki 12 mèn. $10 \%-20 \%$ vartojančiujų tampa priklausomi, o vartojant ilgiau nei metus, šis skaičius išauga iki $20 \%-45 \%$ [15].

Tose pačiose gairèse nurodoma, jog net ir mažomis dozėmis BZD vartojant ilgiau nei 6 sav., tolerancija vaistui bei nutraukimo simptomai pasireiškia $15-50 \%$ pacientų.

BZD sukeliami šalutiniai poveikiai, tokie kaip hipotenzija, galvos svaigimas, atminties susilpnèjimas, sumažejusi psichomotorinè koordinacija, priklausomybè, padidina griuvimų, lūžių, nelaimingų atsitikimų riziką, pablogina socialinę vyresnių žmonių integraciją į visuomenę, ir neabejotinai, nors ir netiesiogiai, didina socioekonominius kaštus (išlaidos gydymui ligoninèje susižalojus, gydytojų konsultacijos, receptų išrašymas ir pan.).

Apskaičiuota, jog BZD vartojimas griuvimų riziką padidina $50 \%$, o dèl to patirtų sužalojimų gydymui ES kasmet išleidžiama apie 1,8 milijardo eurų [16].

Kadangi psichotropinių vaistų vartojimo paplitimas vyresniame amžiuje bei su tuo susijusios problemos aktualios daugelyje pasaulio šalių, iškyla būtinybè ieškoti priemonių joms spręsti.

Suomijoje atliktas tyrimas, kuriuo siekta nustatyti, ar informacijos suteikimas yra veiksminga priemonè mažinant ilgalaikio BZD ir kitų psichotropinių vaistų vartojimo paplitimą [17]. Eksperimentinès grupès dalyviai pakviesti apsilankyti pas gydytoją ir vizito metu buvo patarta nutraukti vaistu vartojimą. Taip pat jie išklausė vienos valandos trukmès paskaitą apie nepageidaujamą vaistų poveikị bei traumų riziką, tuo tarpu kontrolinès grupės dalyviams jokių rekomendacijų pateikta nebuvo. Po 12 mèn. buvo pakartotinai surinkta informacija apie vaistų vartojimą. Tiek reguliariai, tiek nereguliariai vartojančiųų grupėse BZD vartojimo paplitimas sumažèjo (atitinkamai $35 \%$ ir $28 \%$ ) , taigi galima daryti išvadą, kad nors kartą informuojant pacientus pirminėje sveikatos priežiūros grandyje, galima sẻkmingai sumažinti ilgalaikị BZD vartojimą. 1998-2000 m. atlikta plati, prospektyvinè studija tarp ilgai vartojančiųjų BZD pacientų (Benzoredux studija), kurios metu bandyta nustatyti, kokią ịtaką pacientams, ilgą laiką vartojantiems BZD, daro šeimos gydytojo išsiųstas laiškas su rekomendacijomis nutraukti vaisto vartojimą [18]. Rezultatai parodè, kad 28\% dalyvių 3 mèn. neatvyko išrašyti vaistų, $14 \%$ nesikreipe receptų vaistams 21 mèn. po laiško gavimo. Tyrëjai teigia, kad praejjus 10 metų dalyviai, nutraukę vartojimą tyrimo pradžioje, ir toliau BZD nevartojo. Tiems, kuriems nepavyko visiškai atsisakyti vaistų, vartojo juos vidutinėmis ar mažomis dozèmis. Autorių teigimu, rezultatai pateisino šios minimaliai pastangų reikalaujančios strategijos veiksmingumą pirminėje sveikatos priežiūros grandyje.

Tad apibendrinant ịvairių šalių duomenis, daugiau dėmesio turètų būti skiriama išsiaiškinti pakartotinio ir ilgalaikio BZD receptų išrašymo priežastims bei nustatyti, kokios priemonès galètų būti pritaikytos klinikinèje praktikoje. Rizikos faktorių ịvertinimas, pacientų nuolatinis sekimas, kelių skirtingu gydymo būdų pritaikymas, gydant rizikos grupių pacientus, atsakingas receptų rašymas bei paciento informavimas galètų būti tinkamos strateginès priemonès, siekiant sumažinti tiek vartojimo, tiek priklausomybès nuo BZD paplitimą. 


\section{Išvados}

1. Dažniau benzodiazepinų grupès preparatus vartoja moterys, vartojimo paplitimas didèja su amžiumi.

2. Veiksniai, tokie kaip kasdienis vaisto vartojimas, mažos pajamos, žemesnis išsilavinimas, vartojimas dèl nerimo, pensinis amžius, psichinė liga anamnezeje, nuolatinis skausmo jutimas lemia didesnę priklausomybès nuo BZD išsivystymo riziką.

3. Nuosekli ir sistemingai vykdoma programa, tiek šviečiant visuomenę, tiek padedant pacientams individualiai, palaipsniui padètų sumažinti šių vaistų vartojimo mastus.

\section{Literatūra}

1. Fleury MJ, Imboua A, Aubé D, Lambert F, Lambert Y. General practitioners' management of mental disorders: A rewarding practice with considerable obstacles Published online 2012 Mar 16. doi: 10.1186/1471-2296-13-19 https://www.ncbi.nlm.nih. gov/pmc/articles/PMC3355055/

2. Ashton $\mathrm{H}$. The diagnosis and management of benzodiazepine dependence. Curr. Opin. Psychiatry. 2005; 18:249-255. doi: 10.1097/01.yco.0000165594.60434.84. [PubMed] [Cross Ref]. https://doi.org/10.1097/01.yco.0000165594.60434.84

3. Lietuvos Respublikos sveikatos apsaugos ministro įsakymas "Dèl vaistų receptų rašymo ir vaistų išdavimo (pardavimo)". 2002 m. kovo 8 d. Nr. 112, Vilnius.

4. Huerta C, Abbing-Karahagopian V, Requena G, Oliva B, Alvarez Y, Gardarsdottir H. et al.Exposure to benzodiazepines (anxiolytics, hypnotics and related drugs) in seven European electronic healthcare databases: a cross-national descriptive study from the PROTECT-EU Project. First published: 7 July 2015. https://doi.org/10.1002/pds.3825

5. Valius L., Snieganaitė U. Benzodiazepinų naudojimas šeimos medicinos gydytojų praktikoje, LSMU KK Šeimos medicinos centras, 2016.

6. Donato F, Samani F, Marini M, Mazzaglia G, Leggieri G, Balestrieri M. et al. A crosssectional survey on benzodiazepine use among older people in an Italian region. Italian Journal of Public Health 2012;42-48.

7. C. Barnas, W. W. Fleischhacker, A.B. Withworth, P. Schett, C.Stuppack, and H. Hinterhuber Characteristics of benzodiazepine long-term users: investigation of benzodiazepine consumers among pharmacy customers, 1991.

8. Adomaitienè V., Danilevičiūtè V., Leskauskas D., Šepetauskienė E., Putelienė D. Vyresnio amžiaus depresijos ir nerimo sutrikimo diagnostikos ir gydymo tendencijos Lietuvoje. Sveikatos mokslai, 2008; 1:1561-1565.

9. Jui-Hsiu Tsai, Tze-Chun Tang, Yi-Chun Yeh, Yi-Hsin Yang, Tsang Hin Yeung, Shing-Yaw Wang, Cheng-Chung Chen. The Chinese version of the severity of dependence scale as a screening tool for benzodiazepine dependence in Taiwan, 2012.

10. Philippe Voyer RN and PhD, Michel Préville, Marie-Eve Roussel, Djamal Berbichec\&Sarah-Gabrielle Béland. Factors associated with benzodiazepine dependence among community-dwelling seniors pages 101-113; 06 Aug 2009 Canada

11. Aliya Kassam and Scott B Patten. Hypnotic use in a population-based sample of over thirty- five thousand interviewed Canadians; 2006.

12. Deksnytė A., Danilevičiūtè V., Aranauskas R., Keburytė G. Benzodiazepinų išrašymo ir vartojimo tendencijos tarp pacientų, hospitalizuotų i Psichiatrijos skyrių, VU MF Psichiatrijos klinika. Neurologijos seminarai, 2011; 15(48): 103-108.

13. Ahmer S, Salamat S, Khan RA, Igbal SP, Haider II, Khan AS, Zafar M. Pattern of benzodiazepine use in psychiatric outpatients in Pakistan: a cross-sectional survey. Clin Pract Epidemiol Ment Health 2009 Apr; 28;5:9.

14. Windle A, Elliot E, Duszynski K, Moore V. Benzodiazepines prescribing in elderly Australian general practice patients. Aust N Z J Public Health 2007;31:379-81. https://doi.org/10.1111/j.1753-6405.2007.00091.x

15. New South Wales Department of Health. Drug and alcohol withdrawal practice guidelines. North Sydney NSW [Internet]. Jan 2008 [cited 2014 Sept 30] Available from: http://www0. health.nsw.gov.au/policies/gl/2008/pdf/gl2008_011.pdf.

16. Panneman MJM, Goettsch WG, Kramarz P, Herings RMC. The costs of benzodiazepine-associated hospital-treated fall Injuries in the EU: a Pharmo study. Drugs Aging 2003;20(11):833-9. https://doi.org/10.2165/00002512-200320110-00004

17. Maritta Salonoja, Marika Salminen, Pertti Aarnio, Tero Vahlberg and Sirkka-Liisa Kivelä One-time counselling decreases the use of benzodiazepines and related drugs among communitydwelling older persons December 10, 2009. Finland.

18. NAH de Gier WJMJ Gorgels PLBJ Lucassen R Oude Voshaar J Mulder F Zitman Discontinuation of long-term benzodiazepine use: 10-year follow-up. Family Practice, June 2011; 28(3):253-259.

https://doi.org/10.1093/fampra/cmq113

\section{BENZODIAZEPINE DEPENDENCE TENDENCIES AMONG GENERAL PRACTICE PATIENTS ON BENZODIAZEPINES \\ R. Aranauskas, L. Vaičiulienė}

Key words: benzodiazepines use dependence, long-term use, adverse effect.

Summary

BZD prescribing is significantly related to age, gender, chronic illness and health care consumption.

Benzodiazepines (BZD) are the most frequently prescribed drugs in the world. Although it is advised to use BZD for only a short period, it appears that patients take these drugs for much more longer. Long-term or extensive use of these psychopharmacological agents is associated with more severe adverse effects, including memory impairment, depression, tolerance, and dependence. Objective: The aim of this study was to assess the incidence, distribution, and risk factors of benzodiazepine dependence among BZD users in general practice $(n=101)$. Method: Patients of GP 
(General Medical Practicioner) were involved in this study. Eligibility criteria included age greater than 18 years and use of BZD at the time of entry into the study. Using a structured diagnostic interview participants had to answer the questions about their gender, age, personal incomes, education, alcohol using, smoking, point out one or more BZDs, they had taken (presented as a list of brand and generic names). Therefore, for the assessment of BZD dependence, seven questions based on DSM-IV criteria were included. Cronbach alfa was used to establish the internal validity of the scale. Results: BDZ use was more common in women than in men and its frequency increased with age. The mean duration of intake was 86 months. $49,5 \%$ patients admitted to taking BZDs daily. The most frequent reason for BZD intake was sleep disorder. Thirty seven and six percent of BZD users met DSM-IV criteria for BZD dependence. Significant difference observed among daily use $(p<0.01)$, patients with low income $(p=0.013)$, lower education $(p$ $=0.023)$, chronic pain $(\mathrm{p}=0.005)$, psichiatric disorder $(\mathrm{p}=0.027)$ and higher incidence of BZD dependence. Whereas gender, marital status, harmful habits (alcohol use and smoking) were not associated with the incidence of BZD dependence. Conclusions: The observation that BZD use is more frequent in women, increases with age and is higher in low income and education groups, confirms previous findings in other countries. The present study showed that the incidence of BZD dependence is high. Larger studies are warranted to expand these findings and more precisely identify reasons of BZD usage among individuals in general population.

Correspondence to: vaiciulienelaura@gmail.com

Gauta 2018-04-23 